\title{
Potret Kesenjangan Pembelajaran Jarak Jauh
}

\author{
Fa'uzobihi' $^{1}$, Awaluddin Tjalla', ${ }^{2}$ Richardus Eko Indrajit ${ }^{3}$ \\ Sekolah Tinggi Ilmu Ekonomi Pertiwi ${ }^{1}$, Universitas Negeri Jakarta ${ }^{2,3}$ \\ Email: fauzobihi@pertiwi.ac.id
}

\begin{tabular}{l}
\hline Article Info \\
Article history: \\
Article Accepted: 15 July 2021 \\
Publication : 15 July 2021 \\
\\
Keywords: \\
PJJ Evaluation, Disscrepancy \\
Model
\end{tabular}

\begin{abstract}
This article aims to evaluate the impact of long-range pursuit programs using the Disscrepancy Model, developed by Malcolm Provus. Emphasizes the view of gaps in program implementation. The word discrepancy means gap, this model according to Madaus, Sriven \& Stufflebeam (1993: 79-99) departs from the assumption that to find out the feasibility of a program, evaluators can compare what should be expected to happen (standard) with what actually happens (performance). . Comparing the two things, it can be seen whether there is a gap (discrepancy), namely the standard set with the actual performance. This model was developed by Malcolm Provus, aims to analyze a program whether the program is worth continuing, increasing, or terminating. teaching evaluation is a component in the teaching system, while the teaching system itself is an implementation of the curriculum, as an effort to create classroom learning. Oemar Hamalik (2001: 145) states, the evaluation process is generally studentcentered. This means that evaluation is intended to observe student learning outcomes and seeks to determine how learning opportunities are. From the two opinions above, the evaluation is intended to observe a teaching process, which includes the role of the teacher, teaching strategies, curriculum materials, and learning principles applied to teaching.

Abstrak

Artikel ini bertujuan untuk mengevaluasi dampak program pembejaran jarak jauh menggunakan Disscrepancy Model, dikembangkan oleh Malcolm Provus. Menekankan pada pandangan adanya kesenjangan dalam pelaksanaan program. Kata discrepancy berarti kesenjangan, model ini menurut Madaus, Sriven \& Stufflebeam (1993: 79-99) berangkat dari asumsi bahwa untuk mengetahui kelayakan suatu program, evaluator dapat membandingkan antara apa yang seharusnya diharapkan terjadi (standard) dengan apa yang sebenarnya terjadi (performance). Membandingkan kedua hal tersebut, maka dapat diketahui ada tidaknya kesenjangan (discrepancy), yaitu standar yang ditetapkan dengan kinerja yang sesungguhnya. Model ini dikembangkan oleh Malcolm Provus, bertujuan untuk menganalisis suatu program apakah program tersebut layak diteruskan, ditingkatkan, atau dihentikan. evaluasi pengajaran merupakan suatu komponen dalam sistem pengajaran, sedang sistem pengajaran itu sendiri merupakan implementasi kurikulum, sebagai upaya untuk menciptakan belajar di kelas. Oemar Hamalik (2001: 145) menyatakan, proses evaluasi umumnya berpusat pada siswa. Ini berarti evaluasi dimaksudkan untuk menngamati hasil belajar siswa dan berupaya menentukan bagaimana kesempatan belajar. Dari dua pendapat di atas evaluasi dimaksudkan untuk mengamati suatu proses pengajaran, di dalamnya meliputi peranan guru, strategi pengajaran, materi kurikulum, dan prinsip-prinsip belajar yang diterapkan pada pengajaran.
\end{abstract}

This is an open access article under the Lisensi Creative Commons Atribusi-BerbagiSerupa 4.0 Internasional
Keywords:

Evaluasi PJJ, Disscrepancy Model

Corresponding Author:

Fa'uzobihi'

Sekolah Tinggi Ilmu Ekonomi Pertiwi ${ }^{1}$

Email:fauzobihi@pertiwi.ac.id

\section{PENDAHULUAN}

Generasi baru ( generasi X, Generasi Y, Generasi Z dan Generasi Alfa) memiliki nilai-nilai dan perilaku yang khas, berbeda dengan generasi sebelumnya ( silent genertion dan baby boomers). Berdasar beberapa survey sebagian ciri generasi ini hyper- connected melalui internet dan malas (lazy generation) karena dengan kemajuan teknologi digital semua menjadi mudah. Fleksibilitas sangat diinginkan oleh generasi ini. Dalam hal menentukan pilihan studinya, bisa diduga generasi baru ini kurang tertarik dengan metode pembelajaran 
konservatif dan lebih memilih metode pembelajaran yang memanfaatkan teknologi informasi sesuai dengan karakternya.

Disisi yang lain dukungan teknologi informasi yang memungkinkan peserta didik bisa mengakses pendidikan dimanapun dan kapanpun telah dimanfaatkan oleh institusi pendidikan untuk menyelenggarakan pembelajaran secara daring melalui Pendidikan Jarak Jauh dan Massive Open Daring Course's seperti misalnya Class Central udemy, coursera, future learn, Khan Academy . Di Indonesia, Beberapa perguruan tinggi negeri maupun swasta juga sedang mengembangkan penyelenggaraan perkuliahan daring dengan berbagai modus ( blended learning, Ganda kombinasi, Ganda Paralel). Bahkan Kemenristek Dikti dalam beberapa forum memotivasi perguruan tinggi untuk segera menyelenggarakan Perkuliahan daring secara bertahap.

Sekolah Tinggi Ilmu Ekonomi Pertiwi telah memulai menyelenggarakan perkuliahan daring dengan modus blended learning untuk sebagian mata kuliah pada hampir semua Program Studi. Sesuai dengan Peta jalan penyelenggaraan perkuliahan daring yang telah disusun, STIE Pertiwi berkomitmen untuk terus mengembangkan perkuliahan daring sebagai upaya mengantisipasi kebutuhan pendidikan bagi generasi baru. Berdasar komitmen pengembangan PJJ dan dalam rangka meningkatkan serta menjaga mutu lulusan.

Pengertian dari beberapa istilah yang diguanakan dalam konteks penyelenggaraan Pendidikan Jarak Jauh (PJJ) ada jenjang Pendidikan Tinggi, yaitu:

1) Pendidikan Jarak Jauh adalah pendidikan yang peserta didiknya terpisah dari pendidik dan pembelajarannya menggunakan berbagai sumber belajar melalui teknologi informasi dan komunikasi, dan media lain. Secara umum, prinsip dalam penyelenggaraan PJJ meliputi perluasan akses pendidikan yang lebih fleksibel, pemerataan kesempatan mendapatkan pendidikan, dan kualitas. Peserta didik adalah anggota masyarakat yang mengembangkan potensi diri melalui proses pembelajaran yang tersedia pada jalur, jenjang, dan jenis pendidikan tertentu serta telah terdaftar dalam penyelenggaraan program pendidikan atau mata kuliah tertentu

2) Sumber belajar PJJ adalah bahan ajar yang dikembangkan dan disusun dalam berbagai bentuk berbasis TIK yang digunakan dalam proses belajar. Sumber belajar dapat dalam

3) bentuk bahan ajar (tertulis, video, audio), materi tugas, soal ujian/tes maupun bentuk tautan.

4) Belajar mandiri adalah kegiatan belajar atas inisiatif peserta didik dengan bantuan minimal dari pihak lain

5) Belajar terbimbing/terstruktur: proses pembelajaran yang disediakan oleh perguruan tinggi untuk membantu proses belajar peserta didik dalam bentuk tutorial tatap muka dan tutorial daring, dengan mengandalkan bimbingan dosen/tutor secara langsung maupun virtual, secara residensial (mukim) maupun non-residensial (tidak mukim).

6) Bantuan belajar adalah segala bentuk kegiatan pendukung yang dilaksanakan oleh pengelola PJJ untuk membantu kelancaran proses belajar peserta didik berupa pelayanan akademik dan administrasi, maupun pribadi, berbasis TIK.

7) Tutorial adalah bentuk bantuan belajar akademik yang dapat dilaksanakan secara tatap muka maupun melalui pemanfaatan TIK.

8) Evaluasi hasil belajar peserta didik adalah penilaian yang dilakukan terhadap hasil proses belajar peserta didik dalam bentuk tatap muka dan jarak jauh berbasis TIK.

9) Evaluasi hasil belajar secara tatap muka adalah penilaian yang dilakukan dengan pengawasan secara langsung.

Evaluasi pembelajaran merupakan bagian integral dari proses pembelajaran, artinya dalam pembelajaran akan melibatkan tiga aktifitas yaitu perencanaan, pelaksanaan dan evaluasi. Pengukuran dalam bahasa inggris diartikan measurement, dapat diartikan sebagai kegiatan untuk "mengukur" sesuatu. Mengukur adalah membandingkan sesuatu dengan atau atas dasar ukuran tertentu. Penilaian berarti, menilai sesuatu, sedangkan menilai itu mengandung arti: mengambil keputusan terhadap sesuatu dengan mendasarkan diri atau berpegang pada ukuran tertentu. Sedang evaluasi adalah mencakup dua kegiatan yang telah dikemukakan terdahulu, yaitu mencakup pengukuran dan penilaian (Anas Sujiono 2006 dalam Tsalasa 2007: 39). Menurut Sugandi (2006: 109) evaluasi pengajaran merupakan suatu komponen dalam sistem pengajaran, sedang sistem pengajaran itu sendiri merupakan implementasi kurikulum, sebagai upaya untuk menciptakan belajar di kelas. Oemar Hamalik (2001: 145) menyatakan, proses evaluasi umumnya berpusat pada siswa. Ini

berarti evaluasi dimaksudkan untuk menngamati hasil belajar siswa dan berupaya menentukan bagaimana kesempatan belajar. Dari dua pendapat di atas evaluasi dimaksudkan untuk mengamati suatu proses pengajaran, di dalamnya meliputi peranan guru, strategi pengajaran, materi kurikulum, dan prinsipprinsip belajar yang diterapkan pada pengajaran. 
sebabnya evaluasi menempati kedudukan penting dalam rancangan kurikulum dan rancangan pengajaran. Kegiatan evaluasi harus dilakukan secara sistematis yaitu kegiatan pengukuran, penilaian dan akhirnya pengambilan keputusan, untuk pengambilan keputusan sesuai dengan tujuan evaluasi. Dalam melakukan evaluasi hasil belajar dituntut mengevaluasi secara menyeluruh terhadap peserta didik, baik dari segi pemahamannya terhadap materi yang telah diberikan (aspek kognitif), maupun dari segi penghayatan (segi afektif) dan pengalamannya (aspek psikomotorik). (a) Ranah kognitif Ranah kognitif adalah ranah yang mencakup kegiatan mental (otak). Menurut Bloom, segala upaya yang menyangkut aktifitas otak adalah termasuk ranah kognitif. Dalam ranah konitif terdapat enam jenjang proses berfikir, mulai dari jenjang terendah sampai jenjang paling tinggi. Keenam jenjang yang dimaksud adalah: (1) pengetahuan/ hafalan/ ingatan (knowledge), (2) pemahaman (comprehension), penerapan (application), (4) analisis (analysis), (5) sintesis (synthesis) dan (6) evaluasi (evaluation). (b) Ranah psikomotor Ranah psikomotor adalah ranah yang berkaitan dengan ketrampilan (skill) atau kemampuan bertindak setelah seseorang menerima pengalaman belajar tertentu. Hasil belajar ranah psikomotor dikemukakan oleh Simpson (1956) yang menyatakan bahwa hasil belajar psikomotor ini tampak dalam bentuk ketrampilan (skill) dan kemampuan bertindak individu. Ranah afektif Taksonomi untuk daerah afektif mula-mula dikemukakan oleh David R Krathwohl dan kawan-kawan (1974) dalam buku yang diberi judul taxonomy of educational objectives: Avefective domain. Ranah afektif adalah ranah yang berkaitan dengan sikap dan nilai. Seperti: perhatiannya terhadap mata pelajaran agama Islam, kedisiplinannya dalam mengikuti pelajaran agama di sekolahnya, motivasi untuk tahu lebih banyak mengenai pelajaran agama Islam yang diterimanya.

Berdasarkan latar belakang tersebut, artikel ini bertujuan untuk mengevaluasi dampak program pembejaran jarak jauh menggunakan Disscrepancy Model, dikembangkan oleh Malcolm Provus. Menekankan pada pandangan adanya kesenjangan dalam pelaksanaan program. Kata discrepancy berarti kesenjangan, model ini menurut Madaus, Sriven \& Stufflebeam (1993: 79-99) berangkat dari asumsi bahwa untuk mengetahui kelayakan suatu program, evaluator dapat membandingkan antara apa yang seharusnya diharapkan terjadi (standard) dengan apa yang sebenarnya terjadi (performance). Membandingkan kedua hal tersebut, maka dapat diketahui ada tidaknya kesenjangan (discrepancy), yaitu standar yang ditetapkan dengan kinerja yang sesungguhnya. Model ini dikembangkan oleh Malcolm Provus, bertujuan untuk menganalisis suatu program apakah program tersebut layak diteruskan, ditingkatkan, atau dihentikan

\section{METODE PENELITIAN}

Evaluasi kesenjangan program, begitu orang menyebutnya. Kesenjangan program adalah sebagai suatu keadaan antara yang diharapkan dalam rencana dengan yang dihasilkan dalam pelaksanaan program. Evaluasi kesenjangan dimaksudkan untuk mengetahui tingkat kesesuaian antara standard yang sudah ditentukan dalam program dengan penampilan aktual dari program tersebut. Standar adalah kriteria yang telah dikembangkan dan ditetapkan dengan hasil yang efektif. Penampilan adalah sumber, prosedur, manajemen dan hasil nyata. Kata discrepancy adalah istilah bahasa Inggris, yang diterjemahkan ke dalam bahasa Indonesia yang berarti menjadi "kesenjangan". Model yang dikembangkan oleh Malcolm Provus ini merupakan model yang menekankan pada pandangan adanya kesenjangan di dalam pelaksanaan evaluasi. Evaluasi program yang dilakukan oleh evaluator mengukur besarnya kesenjangan yang ada disetiap komponen.

Ada beberapa model yang menunjuk pada langkah-langkah yang dilakukan dalam evaluasi, sebagian lain menunjuk pada penekanan atau obyek sasaran, dan ada yang sekaligus menunjukkan sasaran dan langkah atau pentahapan. Khusus untuk model yang dikembangkan oleh Malcom Provus ini, menekankan pada kesenjangan yang sebetulnya merupakan persyaratan umum bagi semua kegiatan evaluasi, yaitu mengukur adanya perbedaan antara yang seharusnya dicapai. Evaluasi model kesenjangan (discrepancy model) menurut provus (dalam fernandes, 1984) adalah untuk mengetahui tingkat kesesuaian antara baku (standard) yang sudah ditentukan dalam program dengan kerja (performance) sesungguhnya dari program tersebut. Buku adalah kriteria yang ditetapkan, sedangkan kinerja adalah hasil pelaksanaan program.

Macam-macam kesenjangan yang dapat dievaluasi dalam program pendidikan antara lain meliputi :

1. Kesenjangan antara rencana dengan pelaksanaan program.

2. Kesenjangan antara yang diduga atau diramalkan akan diperoleh dengan yang benar direalisasikan

3. Kesenjangan antara status kemampuan dengan standar kemampuan yang ditentukan

4. Kesenjangan tujuan. 
5. Kesenjangan mengenai bagian program yang dapat diubah

6. Kesenjangan dalam sistem yang tidak konsisten.

\subsection{Metode Penelitian}

Langkah-langkah dalam Evaluasi Kesenjangan, langkah-langkah atau tahap-tahap yang dilalui dalam mengevaluasi kesenjangan adalah sebagai berikut:

1. Desain/Definisi

2. Instalasi

3. Proses

4. Produk

5. Membadingkan

Pertama, dalam tahap Desain/Definisi, fokus kegiatan dilakukan untuk merumuskan tujuan, proses atau aktifitas, serta pengalokasian sumberdaya dan partisipan untuk melakukan aktifitas dan mencapai tujuan-tujuan yang telah ditetapkan. Menurut Provus, program pendidikan merupakan system dinamis yang meliputi inputs (antecedent), proses, dan outputs (juga outcomes). Standar atau harapan-harapan yang ingin dicapai ditentukan untuk masing masing komponen tersebut. Standar ini merupakan tujuan program yang kemudian menjadi kriteria dalam kegiatan penilaian yang dilakukan. Tahap Penyusunan Desain, dalam tahap ini dilakukan kegiatan :

a. Merumuskan tujuan program

b. Menyiapkan murid/ mahasiswa, staf dan kelengkapan lain

c. Merumuskan standar dalam bentuk rumusan yang menunjuk pada suatu yang dapat diukur, biasa di dalam langkah ini evaluator berkonsultasi dengan pengembangan program. Sesudah memahami tentang isi yang terdapat di dalam progra myang merupakan objek evaluasi, maka langkah selanjutnya adalah melakukan penyusunan desain. Adapun hal hal yang perlu dilaksanakan, antara lain: a. Latar belakang.

b. Problematika (yang akan dicari jawabannya).

c. Tujuan evaluasi.

d. Populasi dan sampel

e. Instrumen dan sumber data

f. Teknik analisis data.

Kedua, tahap Instalasi, rancangan program digunakan sebagai standar untuk mempertimbangkan langkah-langkah operasional program. Seorang evaluator setidaknya perlu mengembangkan seperangkat tes kongruensi untuk mengidentifikasi tiap kesenjangan antara instalasi program atau aktifitas yang diharapkan dan yang aktual. Hal ini perlu untuk meyakinkan bahwa program telah diinstal sesuai dengan rancangan yang ditetapkan. Pengalaman selama ini menunjukkan bahwa banyak rancangan program yang sama dioperasionalkan oleh guru/ dosen dengan aktifitas yang berbeda-beda. Tahap Instalasi atau Penetapan Kelengkapan Program yaitu melihat apakah kelengkapan yang tersedia sudah sesuai dengan yang diperlukan atau belum. Dalam tahap ini dilakukan kegiatan :

a. Meninjau kembali penetapan standar

b. Meninjau program yang sedang berjalan

c. Meneliti kesenjangan antara yang direncanakan dengan yang sudah dicapai.

Ketiga, pada tahap Proses, evaluasi difokuskan pada upaya bagaimana memperoleh data tentang kemajuan para peserta program, untuk menentukan apakah perilakunya berubah sesuai dengan yang diharapkan atau tidak. Jika ternyata tidak, maka perlu dilakukan perubahan terhadap aktifitas-aktiaitas yang diarahkan untuk mencapai tujuan perubahan perlaku tersebut.

Dalam tahap ketiga dari evaluasi kesenjangan ini adalah mengadakan evaluasi, tujuan tujuan manakah yang sudah dicapai. Tahap ini juga disebut tahap "mengumpulkan data dari pelaksanaan program Keempat, Selama tahap Produk, penilaian dilakukan untuk menentukan apakah tujuan akhir program tercapai atau tidak. Provus membedakan antara dampak terminal (immediate outcomes) dan dampak jangka panjang (long termoutsomes). Dengan pemikiran ini ia mendorong evaluator untuk tidak hanya mengevaluasi hasil berupa kinerja program, tetapi lebih dari itu perlu mengadakan studi lanjut sebagai bagian dari evaluasi.

Kelima, tahap lainnnya yang ditawarkan Provus adalah Analisis BiayaManfaat 
(Cost-Benefit Analysis), dimana hasil-hasil yang diperoleh dibandingkan dengan biaya yang dikeluarkan. Analisis ini menjadi sangat urgen dalam keadaan sumber daya (khususnya biaya) pembangun pendidikan yang sangat terbatas (limited resources). Apapun kesenjangan yang ditemukan melalui evaluasi Provus menganjurkan agar pemecahan masalah dilakukan secara kooperatif antara evaluator dengan staf pengelola program. Proses kerjasama yang dilakukan antara lain membicarakan tentang: 1) mengapa ada kesenjangan,

2) upaya perbaikan apa yang mungkin dilakukan, 3) upaya mana yang paling baik dilakukan untuk memecahkan masalah yang dihadapi.

Evaluator menuliskan semua penemuan kesenjangan untuk disajikan kepada para pengambil keputusan, agar mereka dapat memutuskan kelanjutan dari program tersebut. Kemungkinannya adalah

a. Menghentikan program

b. Mengganti atau merevisi

c. Meneruskan

d. Memodifikasi

Kunci dari evaluasi discrepancy adalah dalam hal membandingkan penampilan dengan tujuan yang telah ditetapkan. Yang menjadi dasar dalam evaluasi program ini adalah menilai kesenjangan, dengan demikian tanpa perlu menganalisis pihak-pihak yang dipasangkan. Kita segera dapat menyimpulkan bahwa model evaluasi kesenjangan dapat ditetapkan untuk mengevaluasi pemrosesan. Dengan adanya penjabaran kesenjangan pada setiap komponen program, maka langkah-langkah perbaikan dapat dilakukan secara jelas.

\section{KESIMPULAN}

Evaluasi kesenjangan program, begitu orang menyebutnya. Kesenjangan program adalah sebagai suatu keadaan antara yang diharapkan dalam rencana dengan yang dihasilkan dalam pelaksanaan program. Evaluasi kesenjangan dimaksudkan untuk mengetahui tingkat kesesuaian antara standard yang sudah ditentukan dalam program dengan penampilan aktual dari program tersebut. Standar adalah kriteria yang telah dikembangkan dan ditetapkan dengan hasil yang efektif. Penampilan adalah sumber, prosedur, manajemen dan hasil nyata. Kata discrepancy adalah istilah bahasa Inggris, yang diterjemahkan ke dalam bahasa Indonesia yang berarti menjadi "kesenjangan". Model yang dikembangkan oleh Malcolm Provus ini merupakan model yang menekankan pada pandangan adanya kesenjangan di dalam pelaksanaan evaluasi. Evaluasi program yang dilakukan oleh evaluator mengukur besarnya kesenjangan yang ada disetiap komponen.

Standar atau harapan-harapan yang ingin dicapai ditentukan untuk masingmasing komponen tersebut. Standar ini merupakan tujuan program yang kemudian menjadi kriteria dalam kegiatan penilaian yang dilakukan.

a. Merumuskan tujuan program

b. Menyiapkan murid, staf dan kelengkapan lain

c. Merumuskan standar dalam bentuk rumusan yang menunjuk pada suatu yang dapat diukur, biasa di dalam langkah ini evaluator berkonsultasi dengan pengembangan program.

Sesudah memahami tentang isi yang terdapat di dalam program yang merupakan objek evaluasi, maka langkah selanjutnya adalah melakukan penyusunan desain. Adapun hal hal yang perlu dilaksanakan, antara lain:
a. Latar belakang.
b. Problematika (yang akan dicari jawabannya).
c. Tujuan evaluasi.
d. Populasi dan sampel
e. Instrumen dan sumber data
f. Teknik analisis data.

Kedua, tahap Instalasi, rancangan program digunakan sebagai standar untuk mempertimbangkan langkah-langkah operasional program. Seorang

i) evaluator setidaknya perlu mengembangkan seperangkat tes kongruensi untuk mengidentifikasi tiap kesenjangan antara instalasi program atau aktifitas yang diharapkan dan yang aktual. Hal ini perlu untuk meyakinkan bahwa program telah diinstal sesuai dengan rancangan yang ditetapkan. Pengalaman selama ini menunjukkan bahwa banyak rancangan program yang sama dioperasionalkan oelh guru-guru dengan aktifitas yang berbeda-beda. Tahap Instalasi atau Penetapan Kelengkapan Program yaitu melihat 
apakah kelengkapan yang tersedia sudah sesuai dengan yang diperlukan atau belum. Dalam tahap ini dilakukan kegiatan : Meninjau kembali penetapan standar

ii) Meninjau program yang sedang berjalan

iii) Meneliti kesenjangan antara yang direncanakan dengan yang sudah dicapai.

Ketiga, pada tahap Proses, evaluasi difokuskan pada upaya bagaimana memperoleh data tentang kemajuan para peserta program, untuk menentukan apakah perilakunya berubah sesuai dengan yang diharapkan atau tidak. Jika ternyata tidak, maka perlu dilakukan perubahan terhadap aktifitasaktiaitas yang diarahkan untuk mencapai tujuan perubahan perlaku tersebut.

Dalam tahap ketiga dari evaluasi kesenjangan ini adalah mengadakan evaluasi, tujuan tujuan manakah yang sudah dicapai. Tahap ini juga disebut tahap "mengumpulkan data dari pelaksanaan program

Keempat, Selama tahap Produk, penilaian dilakukan untuk menentukan apakah tujuan akhir program tercapai atau tidak. Provus membedakan antara dampak terminal (immediate outcomes) dan dampak jangka panjang (long termoutsomes). Dengan pemikiran ini ia mendorong evaluator untuk tidak hanya mengevaluasi hasil berupa kinerja program, tetapi lebih dari itu perlu mengadakan studi lanjut sebagai bagian dari evaluasi.

Kelima, tahap lainnnya yang ditawarkan Provus adalah Analisis BiayaManfaat

(Cost-Benefit Analysis), dimana hasil-hasil yang diperoleh dibandingkan dengan biaya yang dikeluarkan. Analisis ini menjadi sangat urgen dalam keadaan sumber daya (khususnya biaya) pembangun pendidikan yang sangat terbatas (limited resources). Apapun kesenjangan yang ditemukan melalui evaluasi Provus menganjurkan agar pemecahan masalah dilakukan secara kooperatif antara evaluator dengan staf pengelola program. Proses kerjasama yang dilakukan antara lain membicarakan tentang: 1) mengapa ada kesenjangan, upaya perbaikan apa yang mungkin dilakukan, 3) upaya mana yang paling baik dilakukan untuk memecahkan masalah yang dihadapi. Evaluator menuliskan semua penemuan kesenjangan untuk disajikan kepada para pengambil keputusan, agar mereka dapat memutuskan kelanjutan dari program tersebut. Kemungkinannya adalah :

a) Menghentikan program

b) Mengganti atau merevisi

c) Meneruskan

d) Memodifikasi

Kunci dari evaluasi discrepancy adalah dalam hal membandingkan penampilan dengan tujuan yang telah ditetapkan. Yang menjadi dasar dalam evaluasi program ini adalah menilai kesenjangan, dengan demikian tanpa perlu menganalisis pihak-pihak yang dipasangkan. Kita segera dapat menyimpulkan bahwa model evaluasi kesenjangan dapat ditetapkan untuk mengevaluasi pemrosesan. Dengan adanya penjabaran kesenjangan pada setiap komponen program, maka langkah-langkah perbaikan dapat dilakukan secara jelas.

\section{SARAN}

Berdasarkan kajian diatas maka penulis memberikan saran sebagai bahan perbaikan kedepan, Untuk peserta didik: mahasiswa yang tidak mempunyai motivasi belajar yang tinggi agar bisa meningkatkan minat belajar, Untuk pendidik: berubahnya peran pendidik dari yang semula menguasai teknik pembelajaran konvensional, kini juga dituntut mengetahui teknik pembelajaran yang menggunakan teknologi, Proses pembelajaran: memperbaiki dan memodifikasi interaksi antara dosen dan mahasiswa agar mahasiswa itu sendiri bisa mendapatkan values dalam proses belajar dan mengajar; tetap memperhatikan aspek akademik atau aspek sosial dan sebaliknya menghindari aspek bisnis/komersial; agar proses belajar dan mengajarnya tetap ke pendidikan bukan pelatihan.

\section{REFERENSI}

Arikunto,Suharsimi. 2002. Prsedur penelitian Suatu Pendekatan Praktek. Jakarta: PT Adi Mahasatya.

Berrett-Koehler Publisher, Inc.

Darsono, Max. 2000. Belajar dan Pembelajaran. Semarang: CV. IKIP Semarang Perss.

E-learning Suatu Paradigma Pendidikan Era Digital.http://www.kecoakelektronik.net (25 April 2008).

Hamalik,Oemar.2001. Kurikulumdanpembelajaran. Jakarta:BumiAksara

Hamzah. 2006. Perencanaan Pembelajaran. Jakarta: Bumi Aksara

House,Ernest R.(2005). "Qualitative Evaluation and Changing Social Policy", dalam The SageHandbook of Qualitative Research (3rd ed), Norman K. Denzin dan Yvonna S. Lincoln (eds). Sage: Thousand Oaks,London, New Delhi. 
Kasinath, H. M. (2013). Understanding and using qualitative methods in performance measurement. Journal of Educational Studies, Trend and Practices.

Kunandar. (2014). Penilaian Autentik (Pe-nilaian Hasil Belajar Peserta Didik Berdasarkan Kurikulum 2013): Sua-tu Pendekatan Praktis disertai de-ngan Contoh. Jakarta: Rajawali Pers.

Kusumanegara, Solahuddin. (2010). Model dan Aktor Dalam Proses Kebijakan Publik. Edisi pertam. Yogyakarta, Gava Media.

Leiber, Theodor (2018): Impact evaluation of quality management in higher education: a contribution to sustainable quality development in knowledge societies, European Journal of Higher Education.

Leiber, Theodor., Moutafidou, Nana., \& Welker, Bertram. (2018) Impact evaluation of programme review at University of Stuttgart (Germany), European Journal of Higher Education. 